IJMS 16 (1), 57-73 (2009)

\title{
KESAHAN DAN KEBOLEHPERCAYAAN ALAT UKUR ORIENTASI PEMBELAJARAN MATEMATIK (OPM)
}

\author{
ARSAYTHAMBY VELOO \\ ROSNA AWANG HASHIM \\ College of Arts and Sciences \\ Universiti Utara Malaysia, Malaysia
}

\begin{abstract}
ABSTRAK
Alat ukur Orientasi Pembelajaran Matematik (OPM) digunakan untuk mengukur tingkah laku individu berdasarkan lima gagasan iaitu sikap pembelajaran, kebimbangan, tabiat pembelajaran, tingkah laku penyelesaian masalah dan persekitaran pembelajaran dalam Matematik. Kajian ini bertujuan untuk menentukan kesahan, kebolehpercayaan, skala dan hubungan antara gagasan OPM berdasarkan alat ukur "The Study Orientation Questionnaire in Mathematics"(SOM) yang diubahsuai. Kajian ini menggunakan 76 item daripada SOM dengan tambahan sebanyak 17 item untuk mengakses atribut afektif dalam kalangan pelajar. Seramai 195 pelajar tingkatan empat dipilih daripada sebuah sekolah menengah di negeri Kedah yang terdiri daripada 86 (44\%) adalah lelaki dan 109 (56\%) adalah perempuan. Dari segi kesahan alat ukur OPM (93 item), metod back translation digunakan. Data dianalisis dengan menggunakan SPSS versi 12 bagi mengukur kesahan gagasan, ujian Chi-Square (Bartlett's Test of Sphericity) dan Kaiser-Meyer-Olkin (KMO) dan ujian kebolehpercayaan (Cronbach's alpha). Bagi skala LIKERT, WINSTEP versi 3.48 digunakan untuk menentukan bentuk respons yang dikehendaki. Dapatan kajian ini menunjukkan kelima-lima gagasan OPM mempunyai nilai kebolehpercayaan melebihi 0.7. Kesemua gagasan mempunyai hubungan antara satu sama lain dan ini menunjukkan keteguhan untuk mengukur OPM. Skala LIKERT yang pada mulanya mempunyai lima pilihan (12345) dijadikan empat pilihan (12245) dengan menggunakan step measures at interaction. Ini menunjukkan pilihan 3 (tidak pasti) terlindung di bawah pilihan 2 (tidak setuju) adalah respon yang berkadaran yang sama. Kajian ini berjaya membina alat ukur OPM yang mengandungi 72 item. Alat ukur ini telah memenuhi kriteria-kriteria psikometrik seperti kesahan, kebolehpercayaan, skala dan hubungan antara gagasan OPM untuk mengakses gagasan afektif pelajar dalam
\end{abstract}


pembelajaran Matematik. Oleh itu OPM dapat digunakan oleh guru, kaunselor dan pengetua untuk mengakses OPM dalam memahami atribut afektif pelajar dalam pembelajaran matematik.

Kata kunci: Kesahan; kebolehpercayaan; alat ukur orientasi pembelajaran matematik.

\begin{abstract}
Purpose - The Study Orientation Questionnaire in Mathematics (SOM) (Maree, Claassen, \& Prinsloo, 1997) was used to measure individual behaviour based on five factors: study attitude, anxiety, study habits, problem-solving, and study milieu with specific reference to Mathematics. The study aimed to determine the validity and reliability, scale, and the interrelationship among the factors using the revised Study Orientation Questionnaire in Mathematics (SOM). The present study used SOM (76 items) with 17 additional items to assess the affective attributes among secondary school students.

Design/Methodology/Approach - A total of 195 Form Four students, 86 $(44 \%)$ boys and 109 (56\%) girls, were selected from a school in Kedah. Back translation method was used to translate the 93 items in SOM; SPSS version 12 was used to analyse the construct validity by Chi-Square test (Bartlett's Test of Sphericity) and Kaiser-Meyer-Olkin (KMO), and the internal consistency reliability of the instrument (Cronbach's alpha). WINSTEP version 3.48 was used to analyse the LIKERT scale to determine required patterns of responses.
\end{abstract}

Findings - Findings indicated that all five factors were reliable with Cronbach's Alpha of more than 0.70. All factors were related and thus represent a valid measure of SOM. Using step measures at interaction procedures, the initial five-likert-scaling (12345) was reduced to four (12245). The findings suggested that the third choice (not sure) was embedded under the second choice (disagree) indicating similar response pattern.

Originality/Value - The study has successfully revised and validated the final SOM instrument with 72 items. SOM fulfills psychometric criteria such as validity, realiability, scale, and the interrelationship among five factors which asses stduents' affective factors in learning Mathematics. Thus, the instrument can be used by teachers, counselors, and even principals to access OPM in understanding students' study orientation problem in learning Mathematics.

Keywords-Validity; reliability; study orientation questionnaire in mathematics. 


\section{PENGENALAN}

Masyarakat seringkali menimbulkan persoalan "mengapakah terdapat pencapaian yang berbeza antara pelajar dalam sesuatu mata pelajaran?" Dalam matematik umpamanya ada pelajar yang menunjukkan pencapaian yang baik dan ada pula yang terus tercicir dalam menguasai mata pelajaran ini walaupun berhadapan dengan tajuktajuk yang mudah. Terdapat perbezaan antara cara pelajar mengamati dan mempelajari matematik kerana setiap individu mempelajari dan memproses maklumat matematik secara tersendiri. Beberapa sebab telah diutarakan tentang perbezaan pencapaian matematik dan antaranya ialah individu mempunyai orientasi pembelajaran matematik yang berlainan, unik dan tersendiri (Berita Matematik, 1993).

Alat ukur orientasi pembelajaran matematik telah dibangunkan oleh Maree (2002) di Universiti Pretoria Afrika Selatan. Alat ukur ini digunakan untuk mengukur orientasi pembelajaran matematik dalam kalangan pelajar sekolah menengah dan juga pelajar tahun satu di universiti Afrika Selatan.

Konsep pengukuran yang digunakan dalam ujian dan soal selidik perlu diberi perhatian daripada segi kesahan dan kebolehpercayaan. Dalam hal ini setiap pengkaji menggunakan kebolehpercayaan dan kesahan dalam menentukan ketekalan sesuatu alat ukur yang digunakan. Pengukuran perlu untuk menentukan perbezaan antara individu atau antara kumpulan individu pada sesuatu atribut psikologi dan item ujian. Dalam ujian pendidikan dan psikologi alat ukur digunakan untuk mengukur atribut dan kebolehan pelajar. Keberkesanan alat ukur akan memberi kesahan maklumat dalam hasil kajian yang dilakukan. Alat ukur yang digunakan dalam soal selidik perlu diberi perhatian dari segi kebolehpercayaan dan kesahan (Bond \& Fox, 2001). Justeru kajian ini bertujuan untuk menguji kesesuaian OPM dalam konteks Malaysia.

OPM menggunakan lima gagasan iaitu sikap, kebimbangan, tabiat, tingkah laku dalam menyelesaian masalah dan persekitaran dalam pembelajaran matematik (Maree, Claassen \& Prinsloo, 1997; Maree, 2002; Moodaley, Grobler, \& Lens, 2006). Kelima-lima gagasan ini didapati penting untuk penambahbaikan orientasi pelajar dalam pembelajaran matematik. Orientasi pembelajaran matematik pelajar dapat membantu pendidik mengenal pasti kecenderungan pelajar dalam menghadapi ujian matematik. Dengan mengetahui kekuatan dan kelemahan orientasi pembelajaran matematik pendidik dapat membantu dan membimbing pelajar ke arah yang lebih cemerlang dalam matematik. 


\title{
SOROTAN KAJIAN
}

Teori pembelajaran lebih bersifat deskriptif iaitu menghuraikan aktiviti-aktiviti mental yang boleh dilakukan oleh pelajar mengikut perkembangan intelek subjek tertentu. Guru mempunyai pengetahuan mengenai teori perkembangan kanak-kanak dapat memahami cara pelajar belajar, menyelesaikan dan melaksanakan masalah-masalah matematik. Mengikut Skemp (1971) dalam bukunya "The Psychology of Learning Mathematics";

\begin{abstract}
"Problems of learning and teaching are psychological problems, and before we can make much improvement in the teaching of mathematics we need to know more about how it is learned"(ms.14).
\end{abstract}

Pada dasarnya pembelajaran diertikan sebagai suatu orientasi yang membawa perubahan ke atas diri setiap individu. Setelah menjalani orientasi pembelajaran, seseorang itu akan mengetahui, melakukan ataupun berfikir tentang sesuatu yang tidak diketahui sebelumnya. Di samping itu, orientasi pembelajaran tidak dapat dipisahkan daripada aktiviti mendapatkan dan menggunakan pengetahuan. Apabila pengetahuan telah diperoleh dan digunakan, maka perubahan yang diharapkan akan menjadi kenyataan (Wan Zah Wan Ali, 2000).

Justeru itu, pembelajaran yang dibawa kepada pelajar haruslah diteliti dan dikaji tentang kegunaannya. Ia harus dijelaskan kepada pelajar supaya keinginan untuk belajar berkembang dan seterusnya mendorong mereka untuk gigih berusaha. Pembelajaran tidak terasing daripada unsur kemanusiaan. Malah wajar didekati dengan masalah ini berasaskan orientasi pembelajaran pelajar dalam matematik.

Kebanyakan pelajar di sekolah mengalami kesukaran dalam pembelajaran yang mana mereka tidak atau jarang diajar bagaimana hendak belajar. Kesukaran pembelajaran dalam kalangan pelajar hanya sedikit berkaitan dengan kebolehan semulajadi (Lashley \& Best, 2001). Tanggapan seseorang pelajar terhadap pembelajaran mempengaruhi cara pelajar belajar. Walau bagaimanapun, tanggapan menurut Saljo (1982) tidak boleh dianggap sebagai ciri yang stabil, terbina dalam diri seseorang pelajar. Sebaliknya ia tercetus mengikut situasi persekitaran pembelajaran dan budaya yang melingkungi kehidupan pelajar. Sikap memainkan peranan yang penting dalam menilai dan memaksimumkan pembelajaran matematik. Maklumat mengenai sikap pembelajaran 
pelajar dalam matematik dapat memberikan maklum balas yang penting tentang perkembangan dan pembangunan pelajar dalam memahami konsep matematik

Pada amnya diakui bahawa pelajar perlu proaktif dalam proses pembelajaran (Fitzerald, Morrall \& Morrison, 2000). Pelajar tidak seharusnya pasif dan hanya memberi maklum balas kepada rangsangan guru. Sebaliknya, pelajar sendiri harus menjana idea dan mencari peluang belajar di samping boleh bertanggungjawab terhadap pembelajaran mereka sendiri.

Mengikut Gardner dan Miller (1996), pelajar yang berautonomi akan berinisiatif untuk merancang dan melaksanakan program pembelajaran. Mereka berupaya menentukan matlamat pembelajaran mereka sendiri dan mencapai matlamat ini dengan menggunakan peluang yang terdapat di dalam dan di luar bilik darjah. Hal ini bersesuaian dengan individu yang mempunyai minat, kemampuan, gaya dan rentak pembelajaran yang berbeza antara pelajar. Oleh itu, pelbagai pembelajaran diberi penekanan kepada usaha memenuhi keperluan individu yang berbeza dengan persekitaran dan suasana pembelajaran yang kondusif.

Orientasi pembelajaran adalah berasaskan persepsi bahawa hanya pelajar itu sendiri yang boleh melakukan pembelajaran secara optimum. Walau bagaimana cemerlang guru, ibu bapa atau rakan sebaya, tidak mungkin dapat melakukannya untuk pelajar. Ini dikukuhkan lagi melalui pemerhatian bahawa pelajar berbeza antara satu sama lain dari segi gaya, keperluan dan kadar pembelajaran. Adalah penting pelajar menentukan strategi pembelajaran yang terbaik dan sesuai dengan diri mereka. Ini akan menghasilkan individu yang boleh berfikir dan bertanggungjawab ke atas pembelajaran mereka (Pusat Perkembangan Kurikulum, 2001).

\section{OBJEKTIF KAJIAN}

i. Mengenal pasti bentuk respons skala LIKERT orientasi pembelajaran matematik dengan menggunakan Model Rasch

ii. Mengenal pasti kesahan dan kebolehpercayaan alat ukur orientasi pembelajaran matematik versi Bahasa Malaysia 
iii. Mengenal pasti hubungan antara gagasan-gagasan orientasi pembelajaran matematik

\section{METOD KAJIAN}

\section{Persampelan}

Responden kajian adalah seramai 195 pelajar tingkatan empat sekolah menengah kebangsaan di salah sebuah sekolah di daerah Kubang Pasu di negeri Kedah. Daripada 195 pelajar ini $86(44 \%)$ adalah pelajar lelaki dan seramai 109 (56\%) adalah pelajar perempuan.

Data kajian ini dianalisis dengan menggunakan SPSS versi 12 bagi mengukur kesahan gagasan manakala bagi skala likert program WINSTEP (Rasch Model) digunakan untuk menentukan bentuk respons yang dikehendaki.

\section{Alat Ukur OPM}

Soal selidik Orientasi Pembelajaran Matematik (OPM)(Maree, Claassen \& Prinsloo, 1997; Maree, 2002; Moodaley, Grobler, \& Lens, 2006) dikaji dengan menggunakan lima gagasan utama iaitu sikap pembelajaran matematik merujuk kepada perasaan pelajar terhadap pengalaman objektif dan subjektif. Sikap terhadap mempelajari matematik bermanifestasi secara konsisten dan memberi kesan terhadap motivasi, harapan dan minat pelajar berkaitan dengan matematik. Kebimbangan matematik dalam kalangan pelajar berkaitan dengan perasaan yang tidak selesa apabila kebimbangan ini bermanifestasi dengan sendirinya dalam gelagat yang tidak dijangka. Tabiat belajar merujuk kepada metod pembelajaran perolehan, kekonsistenan dan keberkesanan. Tingkah laku dalam menyelesaikan masalah matematik merujuk kepada strategi kognitif dan meta-kognitif yang diamalkan oleh pelajar dalam matematik. Akhir sekali persekitaran mempelajari matematik merujuk kepada faktor-faktor yang berkaitan dengan sosial, fizikal dan pengalaman persekitaran yang dialami oleh pelajar. Pembelajaran yang terlibat adalah khusus dan umum, strategi merumus pembelajaran, pemikiran kritikal dan strategi kefahaman seperti penggunaan yang maksimum termasuk catatan ringkas, jadual dan gambarajah.

Alat ukur OPM digunakan untuk mengukur tingkah laku pelajar berkaitan dengan aspek-aspek pencapaian matematik. OPM 
dibangunkan pada pertengahan tahun 1990 bagi pelajar sekolah tinggi di Afrika Selatan tetapi skop item ini juga boleh digunakan untuk pelajar universiti tahun satu. Setiap gagasan yang digunakan dalam soal selidik Orientasi Pembelajaran Matematik mengandungi beberapa pernyataan untuk mengukur amalan pembelajaran matematik untuk menghadapi ujian atau peperiksaan. Item-item bagi kelima-lima gagasan OPM ditunjukkan dalam Jadual 1.

Jadual 1: Soal Selidik Orientasi Pembelajaran Matematik (OPM)

\begin{tabular}{clc}
\hline Bil & \multicolumn{1}{c}{ Gagasan (OPM) } & Soalan \\
\hline 1 & Sikap dalam Mempelajari Matematik & 25 \\
2 & Kebimbangan Mempelajari Matematik & 19 \\
3 & Tabiat Mempelajari Matematik & 16 \\
4 & Tingkah laku dalam Menyelesaian Masalah Matematik & 17 \\
5 & Persekitaran dalam Mempelajari Matematik & 16 \\
\hline & Jumlah & 93 \\
\hline
\end{tabular}

Item-item Orientasi Pembelajaran Matematik (Maree, Claassen \& Prinsloo, 1997; Maree, 2002; Moodaley, Grobler, \& Lens, 2006) diambil daripada sumber-sumber i - iv (76 item) manakala beberapa item juga diambil daripada sumber v (17 item) oleh pengkaji supaya item-item dapat mengukur atribut orientasi pembelajaran matematik dalam kalangan pelajar.

i. Survey of Study Habit and Attitudes (SSHA)(Du Toit, 1985)

ii. The Learning and Study Strategies Inventory (LASSI) (Weinstein, 1987)

iii. $\quad$ The Motivated Strategies for Learning Questionnaire (MSLQ) (Pintrich, Smith, Garcia, \& McKeachie, 1989)

iv. Informal Study Orientation Questionnaire in Mathematics (Schminke, Maertens, \& Arnold, 1978)

v. $\quad$ Attitude (Daniel, 2000)

Soal selidik Orientasi pembelajaran menggunakan skala LIKERT dengan lima pilihan. Pilihan 1 (sangat tidak setuju), 2 (tidak setuju), 3 (tidak 
pasti), 4 (setuju) dan 5 (sangat setuju). Mengikut Calhoon dan Fuchs (2003) bagi soal selidik yang mempunyai skala likert empat pilihan nilai sikap 2.4 dan kurang menunjukkan sikap yang negatif, skor item antara 2.4 hingga 2.6 dianggap sebagai neutral dan skor yang melebihi 2.6 menunjukkan sikap yang positif. Jumlah skor yang tinggi menunjukkan sikap yang positif terhadap pembelajaran matematik dengan lebih baik. Menurut Nunnally (1978) nilai kebolehpercayaan $\alpha$ melebihi 0.70 adalah tekal.

\section{DAPATAN KAJIAN}

\section{Kesahan Muka Alat Ukur OPM}

Dari segi kesahan muka alat ukur diterjemahkan oleh pengkaji kemudian disemak oleh dua orang pakar bidang bahasa Inggeris di Universiti Utara Malaysia (UUM) dengan menggunakan kaedah back translation (Brislin, 1970). Kemudian soal selidik ini diberikan kepada guru bahasa Melayu yang berpengalaman untuk disemak dari segi struktur ayat setiap item. Selepas itu dua orang guru yang mengajar matematik (Ketua Panitia Pemeriksa Kertas SPM dan Ketua Jabatan Matematik, Institut Perguruan Darulaman) menyemak item-item berkenaan dari segi atribut tentang matematik. Alat ukur ini juga diberikan kepada beberapa orang guru yang mengajar matematik di sekolah menengah untuk dinilai dari segi kandungan item.

Akhir sekali beberapa pelajar yang berkebolehan tinggi, sederhana dan rendah dipilih untuk menguji kefahaman mereka terhadap item yang hendak diukur untuk mendapatkan maklum balas. Pelajar ini juga terdiri daripada bangsa Melayu, Cina dan India. Pelajar-pelajar ini disoal jawab oleh penyelidik tentang kefahaman item alat ukur. Sebelum alat ukur ini diedarkan untuk mendapatkan data bagi kajian ini ia disemak oleh seorang profesor untuk dinilai.

\section{Ketekalan Dalaman dan Kebolepercayaan Soal selidik OPM}

Program kedua iaitu WINSTEP Rasch Model digunakan untuk mengenal pasti bentuk respons dan kekuatan item yang digunakan dalam alat ukur OPM. Data-data yang diperoleh dianalisis dengan menggunakan Model Pengukuran Rasch. Jadual 2 menunjukkan nilai kebolehpercayaan item 0.99 adalah baik dan bersifat unidimensional yang mengambarkan item berinteraksi dengan baik mengikut atribut. Nilai pemisah bagi item 8.79 telah membantu menegaskan pembentukan lima gagasan OPM iaitu sikap, kebimbangan, tabiat, tingkah laku dan persekitaran. Gagasan Sikap (kognitif \& afektif), kebimbangan (kognitif \& afektif) dan tingkah laku penyelesaian masalah (kognitif \& metakognitif). 

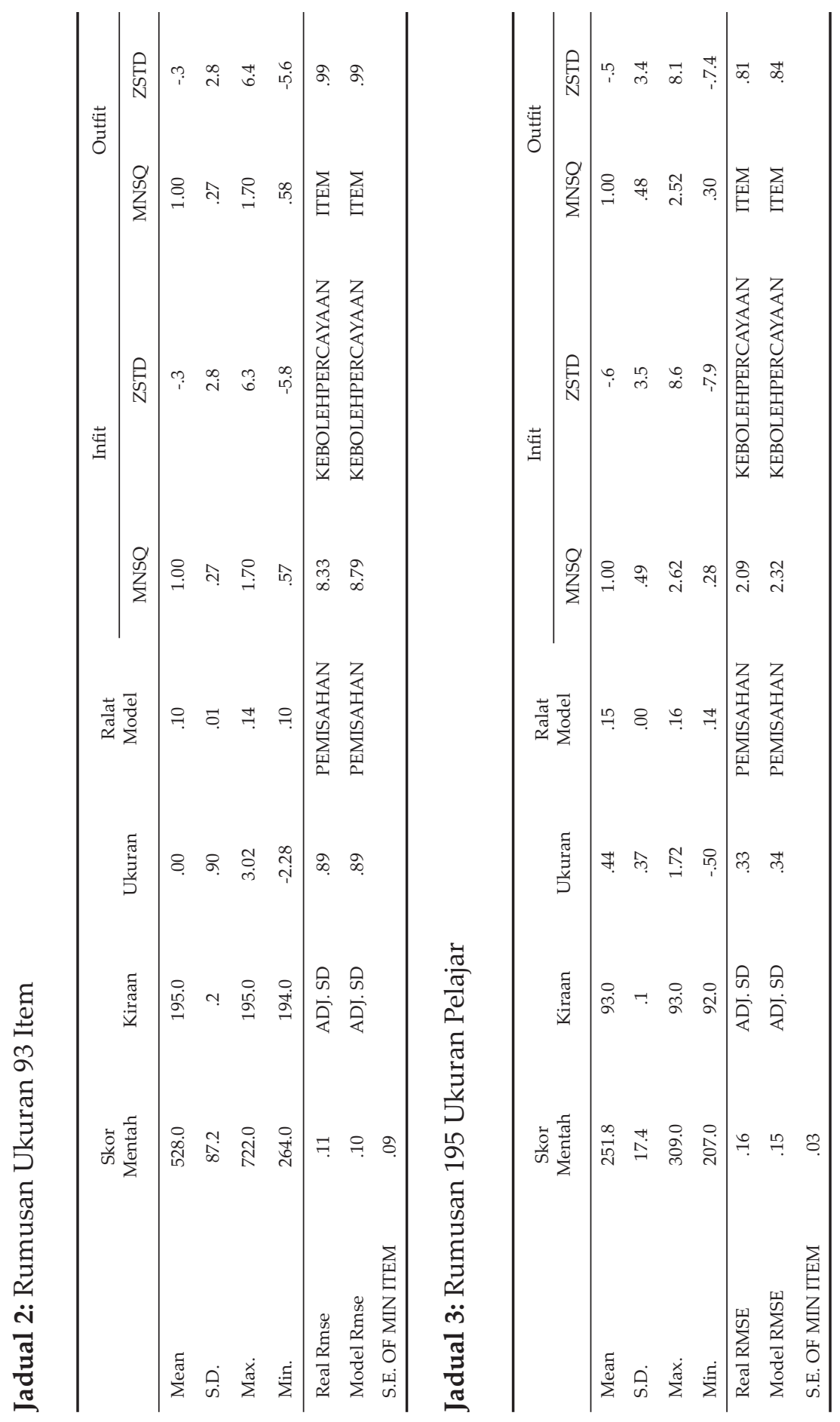

IJMS 16 (1), 57-73 (2009) 
Ralat model adalah masih kecil iaitu 0.10 menunjukkan anggaran kesukaran item adalah hampir tepat dan kesukaran item-item telah mampu disusun mengikut gagasan. Anggaran ketepatan kesukaran item berdasarkan ralat model dan set item-item juga mempunyai ciri-ciri ujian bebas sampel. Anggaran kesukaran item adalah berdasarkan skor setiap item dan tidak dipengaruhi oleh varians sampel. Ujian menunjukkan kesahan dalam yang baik melalui dapatan kebolehpercayaan item (0.99) dan anggaran kesukaran item-item yang menepati model ujian ini mampu memberi anggaran kebolehan pelajar yang sah. Ralat anggaran ukuran pelajar adalah 0.15 dan dianggap menghampiri model dan boleh menggangarkan kebolehan pelajar hampir tepat dengan kebolehpercayaan 0.84 (Jadual 3). Kebolehpercayaan item adalah mencukupi sekiranya melebihi takat minimum 0.70 ke atas bagi sains sosial (Nunnaly, 1978).

Dari segi fungsi kategori padanan item infit dan outfit dapatan menunjukkan nilainya adalah satu iaitu antara 0.7 hingga 1.3. Bagaimanapun bentuk respons skala poin- 5 tidak jelas susunan respons (12345) (Graf 1). Ini menunjukkan skala kategori 3 (tidak pasti) adalah kategori terlindung dibawah kategori 2. Hal ini menunjukkan bahawa semua respons kategori 1245 adalah berfungsi dengan baik berbanding dengan kategori 3.

\section{CATEGORY PROBABILITIES:MODES-Step measures at intersections}

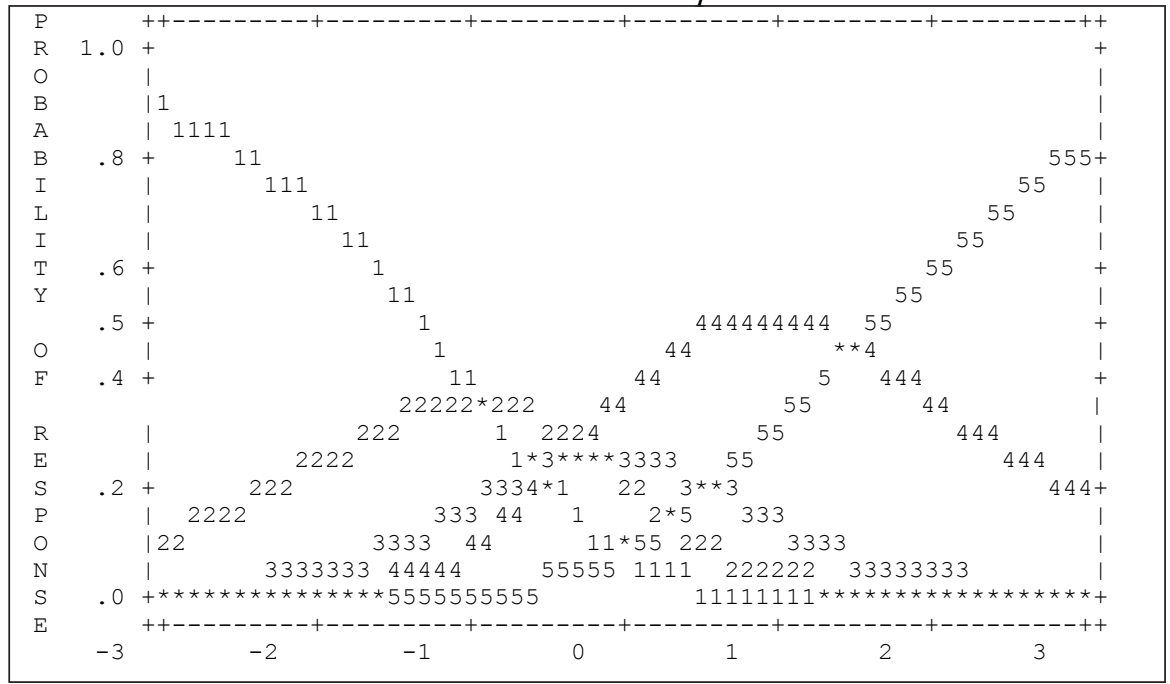

Graf 1: Lengkungan kebarangkalian dan skala poin-5 (12345) 
Berdasarkan dapatan di atas, kategori 3 (tidak pasti) yang terlindung dijadikan sebagai kategori 2 (tidak setuju) iaitu 12245 mengikut skala poin-4 dan keputusannya adalah seperti pada Graf 2. Graf 2 menunjukkan bahawa tiada respons kategori yang terlindung dan dengan itu semua respons 12234 mengikut skala poin-4 berfungsi dengan baik. Oleh itu, OPM berfungsi dengan lebih baik dalam skala poin-4 (12245) berbanding dengan skala poin-5 (12345).

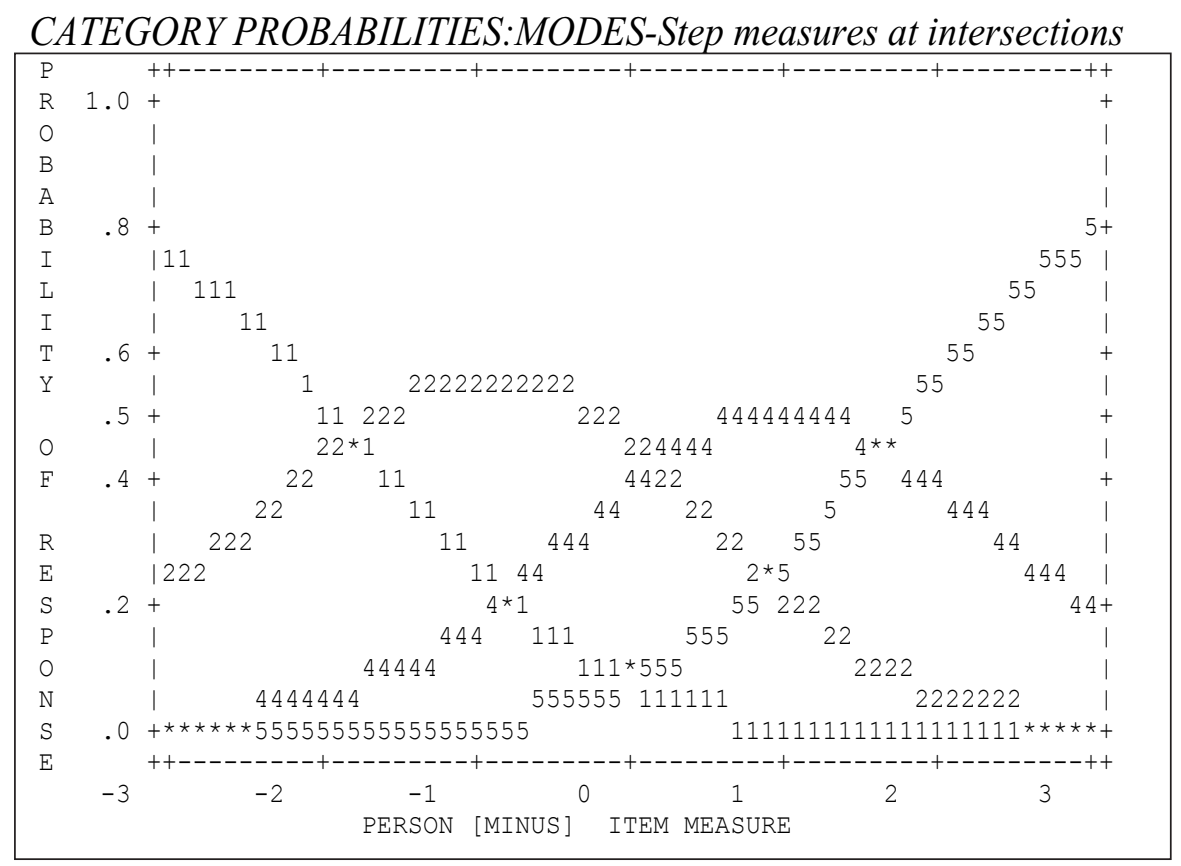

Graf 2: Lengkungan kebarangkalian dan skala poin-4 (12245)

\section{Ketekalan Kandungan Soal Selidik OPM}

Dalam proses terjemahan, penyelidik menggunakan kaedah terjemahan balik (back translation) iaitu item-item diterjemahkan ke dalam Bahasa Melayu dahulu kemudian diterjemahkan kembali ke dalam Bahasa Inggeris bagi mempastikan item-item mempunyai maksud yang sama dengan menggunakan kaedah back translation (Brislin, 1970). Di sini khidmat dua orang pensyarah psikologi dan dua orang pensyarah Bahasa Melayu yang boleh menguasai Bahasa Inggeris telah meneliti dalam proses mendapatkan ketekalan dalaman isi kandungan dan kefahaman bahasa. 


\section{Kesahan Gagasan OPM}

Selepasujianketekalan kandungan, ujiankesahankonstrukdilaksanakan. Jadual 2 menunjukkan ringkasan ujian kesahan bagi setiap konstruk. Kesemua konstruk melepasi ujian matrik identiti dengan kedudukan Bartlett's Test of Sphericity masing-masing adalah signifikan $(\mathrm{p}<.05)$. Semakan terperinci telah dijalankan dan didapati bahawa faktor-faktor yang diterbitkan daripada analisis faktor menepati dimensi asal setelah 21 item digugurkan.

Kajian asal yang dijalankan telah menggunakan sebanyak 93 item untuk mengukur orientasi pembelajaran matematik. Namun demikian, selepas analisis item dan faktor, penyelidik telah menggugurkan sebanyak 21 item termasuk dua item yang menunjukkan korelasi yang sama dengan pemboleh ubah lain. Jadual 2 memaparkan keputusan analisis faktor dengan kaedah cabutan komponen utama (principal components) dan pemutaran paksi varimax. Kriteria nilai eigen lebih daripada satu digunakan untuk menentukan bilangan faktor yang dipilih (extract). Berdasarkan keputusan analisis faktor, 19 item telah digugurkan kerana mempunyai beban faktor (factor loading) yang rendah 0.40 .

Akhir sekali sebanyak 72 item yang digunakan dalam kajian sebenar mempunyai beban faktor yang melebihi 0.4 untuk memenuhi tahap kesahan (Hair, Anderson, Tatham \& Black, 1998). Analisis faktor ke atas setiap gagasan secara berasingan menunjukkan bahawa hanya satu faktor umum yang diterbitkan dan keputusan ini digunakan untuk menyokong kesahan konstruk bagi ke lima-lima gagasan OPM (Jadual $4)$.

Pertama, dapatan daripada analisis faktor terhadap gagasan sikap pembelajaran matematik dalam ujian matrik beridentiti bagi ujian Bartlett's Test Sphericity adalah signifikan $(\mathrm{p}<.05)$ di mana nilai ChiSquare ialah 1138.09 manakala nilai KMO ialah 0.88 .

Jadual 4: Keputusan Ujian Analisis Faktor

\begin{tabular}{lcccc}
\hline $\begin{array}{l}\text { Pemboleh Ubah } \\
\text { Tidak Bersandar }\end{array}$ & $\begin{array}{c}\text { Bil. } \\
\text { Item }\end{array}$ & $\begin{array}{c}\text { Nilai } \\
\text { KMO }\end{array}$ & $\begin{array}{c}\text { Bil. Item } \\
\text { Digugurkan }\end{array}$ & $\begin{array}{c}\text { Total Variance } \\
\text { Explained }\end{array}$ \\
\hline Sikap & 19 & 0.88 & 6 & $52.42 \%$ \\
Kebimbangan & 16 & 0.85 & 3 & $51.86 \%$ \\
Tabiat & 16 & 0.91 & Tiada & $48.35 \%$ \\
Tingkah Laku & 13 & 0.86 & 4 & $44.90 \%$ \\
Persekitaran & 8 & 0.81 & $* 2+6$ & $53.49 \%$ \\
OPM & 72 & 0.89 & 21 & $56.04 \%$ \\
\hline
\end{tabular}

*Digugurkan kerana item analisis 
Di samping itu, nilai keseragaman (communalities) bagi setiap item sikap melebihi 0.50 . Kaedah principal component dijalankan dan didapati dua komponen mempunyai nilai eigenvalue melebihi satu. Kedua, gagasan sikap menyumbang sebanyak $52.40 \%$ daripada jumlah keseluruhan varians. Dapatan daripada analisis faktor terhadap gagasan kebimbangan matematik dalam ujian matrik beridentiti bagi ujian Bartlett's Test Sphericity adalah signifikan $(\mathrm{p}<.05)$ dan nilai Chi-Square ialah 788.05 manakala nilai KMO ialah 0.85 . Seterusnya analisis faktor terhadap gagasan tabiat matematik dalam ujian matrik beridentiti bagi ujian Bartlett's Test Sphericity didapati signifikan $(\mathrm{p}<.05)$ dan nilai Chi-Square ialah 1144.27, manakala nilai KMO ialah 0.91. Dapatan daripada analisis faktor terhadap gagasan tingkah laku penyelesaian masalah matematik dalam ujian matrik beridentiti bagi ujian Bartlett's Test Sphericity didapati signifikan $(\mathrm{p}<.05)$ dan nilai Chi-Square ialah 788.05 manakala nilai KMO ialah 0.86 . Akhir sekali dapatan analisis faktor terhadap gagasan persekitaran pembelajaran matematik dalam ujian matrik beridentiti bagi ujian Bartlett's Test Sphericity mendapati signifikan $(\mathrm{p}<.05)$ dan nilai Chi-Square ialah 1086.19, manakala nilai KMO ialah 0.81 . Ciri-ciri KMO sebagini disebut sebagai meritorious oleh Kaiser (1974). Hal ini menunjukkan bahawa penggunaan analisis faktor adalah sesuai dan ukuran kecukupan sampel adalah munasabah.

\section{Ketekalan Alat Ukur OPM}

Bagi menyiasat kehomogenan (homogeneity), kebolehpercayaan penganggaran kekonsistensi dalaman bagi setiap satu gagasan dikira dengan menggunakan Cronbach Alpha (Jadual 5). Kesemua item menunjukkan nilai korelasi item-total yang agak tinggi kecuali item 13 (0.29) tentang sikap pembelajaran matematik. Nilai Cronbach Alpha bagi gagasan sikap, kebimbangan, tabiat, tingkah laku penyelesaian masalah dan persekitaran pembelajaran matematik adalah $0.89,0.89,0.90,0.83$ dan 0.72. Manakala keseluruhan 72 item dalam alat ukur Oreintasi Pembelajaran Matematik mempunyai nilai alpha yang tinggi iaitu 0.92. Ini menunjukkan bahawa alat ukur OPM mempunyai nilai alpha bagi kelima-lima gagasan dalam orientasi pembelajaran matematik yang melebihi 0.7 . 
Jadual 5: Nilai Kebolehpercayaan mengikut Item, Gagasan dan Alat Ukur

\begin{tabular}{|c|c|c|c|c|c|c|c|c|}
\hline \multirow{2}{*}{$\begin{array}{l}\text { Bil. } \\
1 .\end{array}$} & \multirow{2}{*}{$\frac{\text { Skala }}{\text { Sikap dalam Mempelajari Matematik }}$} & \multirow{2}{*}{$\frac{\text { Item }}{19}$} & \multicolumn{5}{|c|}{$\begin{array}{c}\text { Corrected Item-Total } \\
\text { Correlation }\end{array}$} & \multirow{2}{*}{$\begin{array}{l}\alpha \\
.89\end{array}$} \\
\hline & & & $\begin{array}{l}.66 \\
.67 \\
.62\end{array}$ & $\begin{array}{l}.61 \\
.36 \\
.51 \\
.46 \\
\end{array}$ & $\begin{array}{l}.49 \\
.48 \\
.29 \\
.32 \\
\end{array}$ & $\begin{array}{l}.64 \\
.59 \\
.35 \\
.62 \\
\end{array}$ & $\begin{array}{l}.55 \\
.67 \\
.52 \\
.55\end{array}$ & \\
\hline 2. & $\begin{array}{l}\text { Kebimbangan Mempelajari } \\
\text { Matematik }\end{array}$ & 16 & $\begin{array}{l}.64 \\
.37 \\
.48\end{array}$ & $\begin{array}{l}.65 \\
.55 \\
.53\end{array}$ & $\begin{array}{l}.60 \\
.41 \\
.60 \\
.57\end{array}$ & $\begin{array}{l}.52 \\
.64 \\
.49\end{array}$ & $\begin{array}{l}.60 \\
.44 \\
.67\end{array}$ & .89 \\
\hline 3. & Tabiat Mempelajari Matematik & 16 & $\begin{array}{l}.55 \\
.68 \\
.69\end{array}$ & $\begin{array}{l}.74 \\
.41 \\
.54\end{array}$ & $\begin{array}{l}.61 \\
.45 \\
.56 \\
.54 \\
\end{array}$ & $\begin{array}{l}.66 \\
.59 \\
.56\end{array}$ & $\begin{array}{l}.33 \\
.59 \\
.70\end{array}$ & .90 \\
\hline 4. & $\begin{array}{l}\text { Tingkah Laku dalam Menyelesaikan } \\
\text { Masalah Matematik }\end{array}$ & 13 & $\begin{array}{l}.57 \\
.39\end{array}$ & $\begin{array}{l}.37 \\
.59 \\
.57 \\
\end{array}$ & $\begin{array}{l}.37 \\
.43 \\
.41 \\
\end{array}$ & $\begin{array}{r}.50 \\
.38 \\
.53 \\
\end{array}$ & $\begin{array}{l}.53 \\
.52\end{array}$ & .83 \\
\hline 5. & $\begin{array}{l}\text { Persekitaran dalam Mempelajari } \\
\text { Matematik }\end{array}$ & 8 & .40 & $\begin{array}{l}.38 \\
.48\end{array}$ & $\begin{array}{l}.33 \\
.51\end{array}$ & $\begin{array}{l}.38 \\
.34\end{array}$ & .45 & .72 \\
\hline & OPM & 72 & & & & & & .96 \\
\hline
\end{tabular}

Jadual 6 memaparkan korelasi antara gagasan-gagasan orientasi pelajar dalam pembelajaran matematik. Kesemua gagasan masing-masing mempunyai korelasi positif dan negatif yang signifikan. Dengan itu bolehlah dikatakan pada umumnya gagasan tersebut mempunyai nilai kesahan yang memuaskan dan berjaya mengukur gagasan orientasi pelajar. Maka gagasan-gagasan ini adalah sesuai digunakan dalam kajian ini untuk mengukur orientasi pelajar. Kesimpulannya, dapatan kajian ini adalah agak konsisten dari segi pendekatan penilaian orientasi pelajar.

Jadual 6: Keputusan Ujian Korelasi antara Dimensi-dimensi Orientasi Pelajar

\begin{tabular}{lccccc}
\hline Dimensi Orientasi Pelajar & $(1)$ & $(2)$ & $(3)$ & $(4)$ & $(5)$ \\
\hline 1. Sikap & 1.00 & & & & \\
2. Kebimbangan & $-.61^{* *}$ & 1.00 & & & \\
3. Tabiat & $.82^{* *}$ & $-.50^{* *}$ & 1.00 & & \\
4. Masalah & $.73^{* *}$ & $-.40^{* *}$ & $.76^{* *}$ & 1.00 & \\
5. Persekitaran & $.46^{* *}$ & $-.60^{* *}$ & $.42^{* *}$ & $.34^{* *}$ & 1.00 \\
\hline$* * \mathrm{p}<.05(2-$ ekor $)$ & & & & &
\end{tabular}




\section{PERBINCANGAN}

Akhir sekali soal selidik orientasi pembelajaran matematik melalui analisis item dan faktor mengekalkan sebanyak 72 item daripada 93 item. Sementara itu, kategori 3 (tidak pasti) yang tidak berfungsi dengan baik dijadikan sebagai kategori 2 (tidak setuju). Sementara itu OPM yang berskala empat berfungsi dengan lebih baik berbanding dengan skala 5 . Masa yang diambil untuk menjawab soal selidik adalah antara 20 hingga 25 minit mengikut pemerhatian pengkaji. OPM memainkan peranan yang penting dalam menilai dan memaksimumkan pembelajaran matematik. Dapatan kajian menggunakan OPM untuk memberikan maklumat yang penting tentang perkembangan dan pembangunan pelajar dalam memahami konsep matematik.

Bagi menyiasat kehomogenan lima gagasan, kebolehpercayaan penganggaran kekonsistensi dalaman bagi setiap satu gagasan dikira dengan menggunakan Cronbach Alpha. Kesemua item menunjukkan nilai korelasi item-total yang agak tinggi kecuali item 13 (0.29) tentang sikap pembelajaran matematik. Nilai alpha bagi sikap, kebimbangan, tabiat, tingkah laku penyelesaian masalah dan persekitaran pembelajaran matematik adalah melebihi 0.70 .

Menurut Frienderberg (1995) ujian psikologi yang bersifat piawai dianggap baik dan ujian ini mampu mempunyai nilai ketekalan dalaman yang melebihi 0.80 . Dapatan kajian menunjukkan nilai alpha kesemua gagasan dalam OPM melebihi 0.8 kecuali gagasan persekitaran pembelajaran matematik (0.72). Namun menurut Nunnaly (1978) pula, kebolehpercayaan melebihi 0.70 adalah boleh diterima pakai. Berdasarkan kepada penyataan ini alat ukur OPM dengan versi 72 item telah menunjukkan sifat kebolehpercayaan ketekalan dalaman yang baik kerana melepasi kedua-dua tahap yang dibincangkan. Disamping itu hubungan yang signifikan antara setiap gagasan OPM (Sikap, kebimbangan, tabiat, tingkah laku \& persekitaran) dapat menyumbang dalam mengukur OPM secara menyeluruh.

Kesimpulanya keputusan kajian ini telah berjaya membentuk satu alat ukur OPM yang mengandungi 72 item yang diuji kepada 195 pelajar sekolah menengah kebangsaan. Alat ukur ini juga telah memenuhi kesemua kriteria psikometrik seperti kesahan, kebolehpercayaan dan hubungan antara pemboleh ubah OPM. Oleh itu OPM dapat digunakan oleh guru, kaunselor mahupun pengetua untuk mengakses OPM dalam kalangan pelajar sebelum pengajaran mengambil tempat di dalam bilik darjah. 


\section{RUJUKAN}

Berita Matematik, (1993). Sahsiah Pembelajaran Matematik, 42, Pusat perkembangan Kurikulum, Kementerian Pelajaran Malaysia.

Bond, T.G., \& Fox, C.M. (2001). Applying the rasch model: Fundamental, measurement in the human sciences. London: Lawrence Erlbaum Associates.

Brisline, (1970). Back translation for cross-cultural research. Journal of Cross-Cultural Psychology, 1, 185-216.

Calhoon, M. B., \& Fuchs, L. S. (2003). The effects of peer-assisted learning strategies and curriculum-based measurement on the Mathematics performance of secondary students with disabilities. Remedial and Special Education, 24(4), 235-245.

Daniel, H. J. (2000). Students self-beliefs and science achievement in Ireland: Finding from third International Mathematics and Science Study (TIMSS). International Journal of Instructional Media, 27, 1-32.

Du Toit, L. B. H. (1985). Survey of Study Habits and Attitudes (SSHA). Human Sciences Research Council. Pretoria University, South Africa.

Fitzerald, S., Morrall, A., \& Morrison, B. (2000). Catering for individual learningstyles: Experiences of orienting students in an Asian self-access centre. Retrieved September 17, 2005 from http://elc.polyu.edu .hk/CILL/staff/auto 2000.htm.

Friendenberg, L. (1995). Psychological, testing design, analysis and use. The university of Nort corolina at Asheville, Allyn and Bacon.

Gardner, D., \& Miller, L. (1996). Task for independent language learning. Virginia, USA: TESOL.

Hair, J. F., Anderson, R. E., Tatham, R. L., \& Black, W. C. (1998). Multivariate data analysis. New Jersey: Prentice-Hall.

Kaiser, H. F. (1974). Little jiffy, Mark iv. Educational and psychological measurement, 34, 111-117.

Lashley, C., \& Best, W. (2001). 12 Steps to study success. London: Continuum.

Maree, J.G. (2002). Study orientation: Maths questionaire SOM. Human Sciences. Research Council. Pretoria University, South Africa.

Maree, J. G., Claassen, N. C. W., \& Prinsloo, W. B. J. (1997). Development of a study orientation questionnaire in Mathematics (SOM). South African Journal of Psychology, 28(28). 101-106.

Moodaley, R. R., Grobler, A. A., \& Lens, W. (2006). Study orientation and causal attribution in mathemathics achievement. South African Journal of Psychology, 36(3), 634-655.

72 IJMS 16 (1), 57-73 (2009) 
Nunnaly, J. C. (1978). Psychometric theory (2nd ed.). USA: McGraw-Hill. Pintrich, P. R., Smith, D. A., Garcia, T., \& McKeachie, W. J. (1989). A manual for the use of the motivated strategies for learning questionaire (MSLQ). Ann Arbor, MI: NCRIPTAL, The Univercity of Michigan.

Pusat Perkembangan Kurikulum. (2001). Pembelajaran Akses Kendiri, Pusat Perkembangan kurikulum, Kementerian Pelajaran Malaysia.

Saljo, R. (1982). Learning and understanding. A study of differences in constructing means from a text. (Goteborg Studies in Educational Science 41). Goteborg: Acta Universitatis Gothoburgensis.

Schminke, C. W., Maertens, N., \& Arnold, W. (1978). Teaching the child mathematics. New York: Holt, Rinehart \& Winston.

Skemp, R.R. (1971). The psychology of learning mathematics. Middlesex: Penguin Book Limited.

Wan Zah Wan Ali. (2000). Memahami pembelajaran. Kuala Lumpur: Utusan Publication.

Weinstein, C. E. (1987). LASSI: Learning and study strategies inventory. User's manual. Clear Water, South Africa: H \& H Publication. 